- FINANSE I PRAWO FINANSO WE.

- Journal of Finance and Financial Law

Wrzesień/September 2018 • vol. 3(19): 25-39

https://doi.org/10.18778/2391-6478.3.19.03

\title{
SOURCES OF INCOME AMONG POLISH STUDENTS \\ FROM SILESIAN REGION, THEIR ATTITUDE TO SAVING, INVESTING AND RISK
}

Wioleta Kałuża, Dagmara Brocka Uniwersytet Ekonomiczny w Katowicach

\begin{abstract}
The purpose of this article is to examine the attitude to saving, investing and risk of students, as an important group of potential clients of financial institutions. Students who are just entering the financial markets and are getting familiar with the offer constitute a large potential target group. In this paper, published research show how students manage their funds from various sources, as well as their willingness to use the savings and investment offer. It is also shown to what extent students use the offer available, their attitude to using the offer and their financial awareness which has an impact on the complacency on the financial markets.
\end{abstract}

Keywords: saving, investing, risk, financial literacy, financial inclusion, students' personal finance, financial markets offer, complacency on financial market.

JEL Class: E20, D81, D14. 


\section{INTRODUCTION}

Considering changes in the economic environment, the knowledge of basic financial instruments should be commonly known. This especially applies to the young generation who is entering their adulthood and labour market [OECD 2014: 36]. The students who already obtain some income are current or potential participant of financial markets. Nowadays the important problem on the financial markets is an insufficient level of financial inclusion which is understood as the availability and use of basic financial services, such as having a bank account, savings, loans [Frączek 2015: 19-20]. Young people, as future participants of financial markets, play a spetial role in the process of expanding financial inclusion [Frączek 2015: 19-20]. They constitute wide group of potential users of financial instruments and require special attention from financial institutions. Therefore, participation of youth in the financial market is very important and is determined by various factors.

Regarding general factors influencing financial inclusion and affecting access to financial services many of them can be mention. Some of the majors factors are:

- psychological and cultural barriers,

- low income (lack of stable employment),

- lack of basic education and financial literacy,

- attractiveness of the products offer [Das 2015: 17].

Extensive research was carried out on the entire population of adults, with the division into countries and target groups, presented in The Little Data Book on Financial Inclusion [2015 Little Book..., 2015: 122]. However, there are only a few studies that pay attention to the relationship between the type of income being achieved and the using of financial services among young people. The fact of obtaining income, its source and size largely determine the degree of participation of youth in the financial market [Frączek 2015: 22-25].

Many research proved that regarding age level financial literacy follows an inverted U-shape. It indicates that financial knowledge, awareness, and skills are lower among youth and elderly in comparison to middle-aged adults. It is also proven that a U-shaped age-related curve reflects the prices people are willing to pay for particular financial products, e.g. use of credit cards. The relation of age and risk tolerance was also documented, in general, risk tolerance decreases with aging. Contemporaneously, it also affects the behaviour of individuals on financial markets regarding spending money, savings and portfolio decisions [Frączek i Klimontowicz 2015: 62-84].

The financial knowledge of the consumers should include skills related to the assessment of financial risk and their financial capacity, as well as the ability 
to take effective actions to improve their financial situation [Kiezel i Burgiel 2017: 70]. In case when consumers have small or no experience, they are guided by the experience of other people, most often by their families [Światowy 2006: 102-107], they use information provided by financial institutions or mass media [Smyczek 2007: 200].

Young people, like the old ones, are characterized by a lower propensity to save in comparison to middle-aged people. The level of savings is influenced, among others, by psychological, social and cultural factors. The approach to material things is largely shaped by family traditions in the field of saving [Frączek 2012: 87-98]. Research has been conducted which shows the connection between financial education and readiness to savings. Other research shows that individuals who participate in course connected with personal finance in their high school times save more in their middle-age than those who do not participate in such courses [Frączek i Klimontowicz 2015: 68].

The aim of the paper is to check whether there is a correlation between source, level of income, the effort made to achieve the income and attitude towards saving and making investment decisions among Polish students from Silesian region. The reason we chose students as our respondents is that people obtaining higher education should be characterized by a higher quality of financial literacy, what have a bearing on financial inclusion and conscious use of financial instruments.

\section{METHODOLOGY}

To achieve the goal of research, we will carry out theoretical and empirical research. Theoretical part of research will be focused on management of personal finance among Silesian students, their sources of income and attitude to saving, investing, and risks. And in this part polish and foreign reviewed books and articles, studies of the financial products based on financial institution's current offer, reports of research institutions, data from the Internet will be used.

On the other hand, the basis for inference were the results of primary research. Using the random method a sample of 389 students was selected from among all full-time students of the four leading universities in Katowice: 100 students of University of Economics, 100 law students of Silesian University, 100 students of Silesian University of Technology and 89 students of Academy of Physical Education. The research was carried out in the first quarter of 2018.

The results coming from questionnaires has provided a comprehensive range of information about:

- sources of raising funds (form of employment),

- most common spendings during studies, 
- attitude and preferences toward saving in low risk financial instruments,

- attitude and preferences toward investing in risky financial instruments,

- the most common source of financial knowledge among youth.

The questionnaire contained only closed-end questions with both single and multiple-choice answers. The universities participated in research are typical state universities from Silesian region, where students-respondents are characterized by a number of similar features, including: the structure of gender, age, differences in the size of the city, level of income. That is why it can be assumed that the selected research sample is a miniature of the population of students of different areas of study.

\section{SOURCES OF STUDENT'S INCOME AND PRODUCTS OFFER ON FINANCIAL MARKET REGARDING SAVINGS AND INVESTING}

The attitude towards money and risk - as the most important criteria of financial decision making depends on many factors such as level of income, financial literacy, psychological and cultural background (breeding), worldwide and local economic and political situation, interest rates and fiscal factors [Frączek 2012: 89]. It refers to many target groups, including young people. The source of raising funds can be also mention as very important, and gaining even more importance as a factor influencing the informed participation in financial markets, especially in case of youth.

The effort associated with raising found also can be significant. The source of funds, an experience of financial management and the effort made to obtain the money influence the proportion of saving and spending money, and simultaneously the degree of using the basic financial products (using accounts, savings and loan products). In particular, the effort to take up a job can affect the attitude towards money. The experience gained and positive financial habits can increase consumer safety in the financial market. Furthermore, the knowledge and familiarization with the product offer enable efficient activity on the market and making appropriate decisions [Frączek 2010: 223-247].

Due to the low and not regular students income, financial institutions creating offer should focus on savings and investment products. Students income is usually low so they are not able to secure loans and credits, therefore they rarely use this offer. An exception is student loans, which are repaid after graduation anyway.

The subject of student's income and its structure in literature is rarely discussed and slightly developed. The income of students come from various sources. The following sources can be found in the literature on the subject: 
- pocket money received most often from parents,

- funds earned by them during their studies,

- funds saved before studies,

- scholarships: scientific, social, etc.

- family or health pensions,

- a shared marital budget,

- loans for students,

- other [Jarecki 2010: 21-25].

In addition, students receive financial support through subsidies for loans, dormitory fees as well as various student discounts in the area of culture, entertainment or transport.

Persons aged 19-24 constitute $7 \%$ of the total population of Poland, however, taking into account professionally active people (age range 18-59 / 64) this group constitutes $11 \%$ [Stan $i$ struktura...]. It is a group of potential clients of financial institutions, which cannot be left without a suitable offer. The product offer should include both saving and investments possibilities.

Nowadays, there are two main tendencies on polish financial market regarding the form of financial offer. The financial institutions widen their offer based on what is currently available on the market. On the other hand, they try to adjust the offer to meet the demands of target groups. Within the confines of diversification they reach new intended audience. Recently financial institutions spotted potential in the group of youth, and we can observe broader offer for the youngest customers [Smyczek 2012: 87].

In relation to possibilities of saving there are two leading products in the offer of all the Polish banks. The first product is a deposit. The interest rate is quite low, and invested money is frozen for the period of duration of the contract. There is a possibility of withdrawing the money but it may be associated with an additional fee or losing the interest. The second product is an open savings account. It is characterized by higher flexibility regarding lodging and withdrawing the money but interest rate is even lower than in deposit.

There is also a possibility to spend the savings on other safe financial instruments which are bonds. The bonds are debt securities in which an investor loans money to an entity. The bondholder receives periodically due interest, and on the maturity date - the return of the nominal value. The bonds may be issued by the State Treasury, a commune or a private enterprise. The interest rate is relatively low, depends on the issuer's creditworthiness and is commensurate with the risk incurred. A common method of accumulating cash is to leave it on the current account. In this way, it is not possible to multiply your capital, but it can be freely disposed of [Oferta dla klientów indywidualnych - oszczędności...].

The range of investment products is much wider and is changing constantly. Financial institutions are chasing in creating new products and launching new 
offer incessantly. However, they are less popular among Poles than saving products [Baranowska-Skimina 2011]. If they decide to invest surplus of money they make for investment fund. By this kind of investment customers gain wide selection of investment opportunities, are supported by experts regards managing of financial means. Fund's capital derives from numerous investors and is used to jointly acquire securities. It leads to lowering of investment fees, compared to investors who operate alone. The main feature of the fund is that investors keep control over their shares [www1]. There is also a possibility to invest savings in stocks. The stocks are equity financial instruments which confirms the share in the capital of the listed companies. They allow participation in profits, as well as participation in decision-making activities of the entity during the general meeting of shareholders [Kenny 2017]. The form of investment that enable to achieve high profits is the investment in currency. It is possible to earn both on increases and decreases of exchange rates. However, due to high fluctuation in the money market, investing in currency is associated with a high risk. Long-term investment projects include investments in metals and precious stones as well as in real estate. These investments, however, are associated with the significantly higher expenditure of money in the beginning. The investment returns after a long period of time, in connection with it the risk also increases. There are many options to invest money, new financial instruments and methods of investing are appearing continuously [Smyczek 2001: 105-130]. Investments can be made directly or indirectly. It can be done individually, through the stock exchange or brokerage services. The choice of the form of investment depends only on the amount of funds available and willingness to take the risk [Oferta dla klientów indywidualnych-inwestycje...].

\section{RESULTS OF RESEARCH}

In the research conducted on the basis of the questionnaires, data were collected on the sources of raising fund, students spending's, attitude and preferences toward saving in low-risk financial instruments and toward investing in risky financial instruments, as well as the source of financial knowledge. The respondents were the full-time students of various faculties from the University of Economics (UE), Silesian University (SU), Academy of Physical Education (APE) and Silesian University of Technology (SUT). The reason for this division was achieving the data from respondents representing formal financial education - students of Finance and Accounting from the University of Economy, in comparison with students from other universities with education paths not related to finance. 
As pointed out earlier, source and level of income determine the extent of participation in financial markets and may influence the decision making in the scope of saving and taking investment risk. Thus the research started by finding out the level and sources of students income.

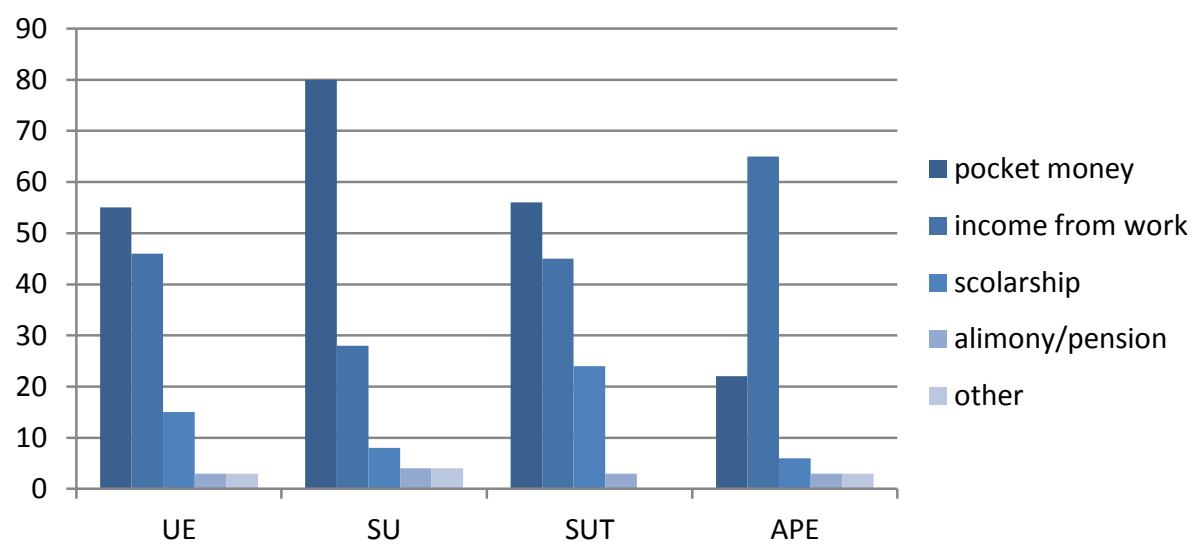

Figure 1. Sources of raising funds by Silesian students

Source: Primary research.

The main sources of income of students are pocket money (45\%) and income from work (39\%). They receive less money from the scholarship (11\%) and pensions/alimony (3\%) and other (2\%). It is worth mentioning that around $18 \%$ of students declared double source of money. For law students, pocket money is the dominant source of income (65\%), unlike students of Academy of Physical Education who raise money mainly from work (66\%). Regarding the type of employment the leading are odd job (39\%) and part-time job (36\%). $15 \%$ of students performs seasonal job, $5 \%$ of them have full time job. Only $2 \%$ of students are self-employed, $3 \%$ of them have other type of employment (e.g. without a formal contract).

Majority of students receive income up to 1000 PLN (46\%). Second most popular income range declared by students is in the range of 1000-2000 PLN (40\%). Only $10 \%$ of students receive income in the range 2000-5000 PLN. Least students (4\%) declare income above 5000 PLN (mainly students of law -9\%).

When it comes to student's spending, in general the largest average proportion is food (19\%). Transport (16\%), entertainment (14\%), clothes (13\%) and education $(10 \%)$ are the next big expenses groups. Students spend the money also on traveling (8\%), household spending (7\%), health $(5 \%)$, 
Internet/telephone (4\%) and others (4\%). Inappreciable percentage of the student $(0,25 \%)$ budget is spent on debt repayments. There are no significant differences between universities.

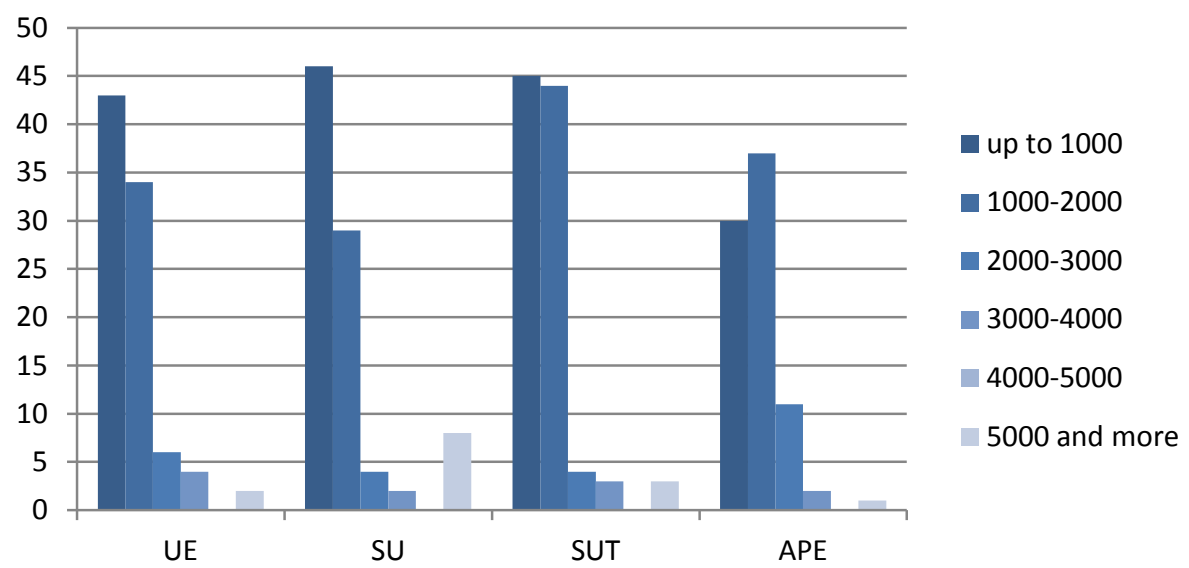

Figure 2. Level of income among Silesian students in thousands PLN

Source: Primary research.

When making settlements, students usually use payment cards (34\%) and cash $(33 \%)$. It should also be stressed that the vast majority of students have an account in a supervised financial institution (93\%). Credit cards are not common among students, only $6 \%$ of students have one. Money transfers via Internet are also in use (27\%). Interestingly, making payments via mobile applications is unpopular among students, only $6 \%$ of students use this method of payment.

Students declare their readiness to save money in safe financial instruments (86\%), however, in the last 12 months, just over half of the students (54\%) have had savings. Around one third of the student's income is spent on savings. Students of law are the most inclined to spare (62\%), and the less students of Academy of Physical Education (48\%).

The most frequently choose form of savings is the open saving account (46\%). Besides students tend to leave money surplus on the current account $(26 \%)$. One quarter of students have money on the deposit. The less popular form of savings are bonds (2\%). Students prefer long-term savings (65\%) rather than short-term savings (35\%). The source and level of income have no significant impact on students savings decisions. There are no significant differences between universities. 


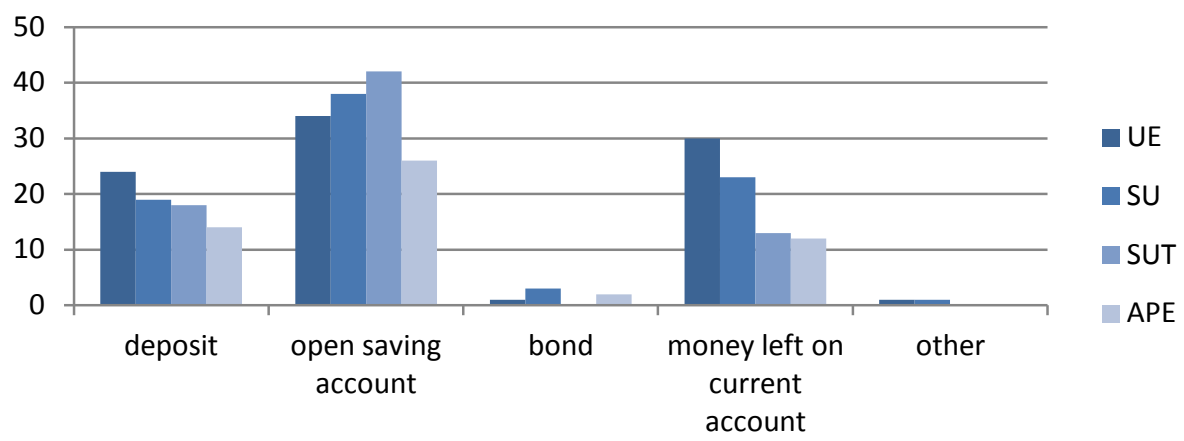

Figure 3. Forms of safe financial instruments used by Silesian students Source: Primary research.

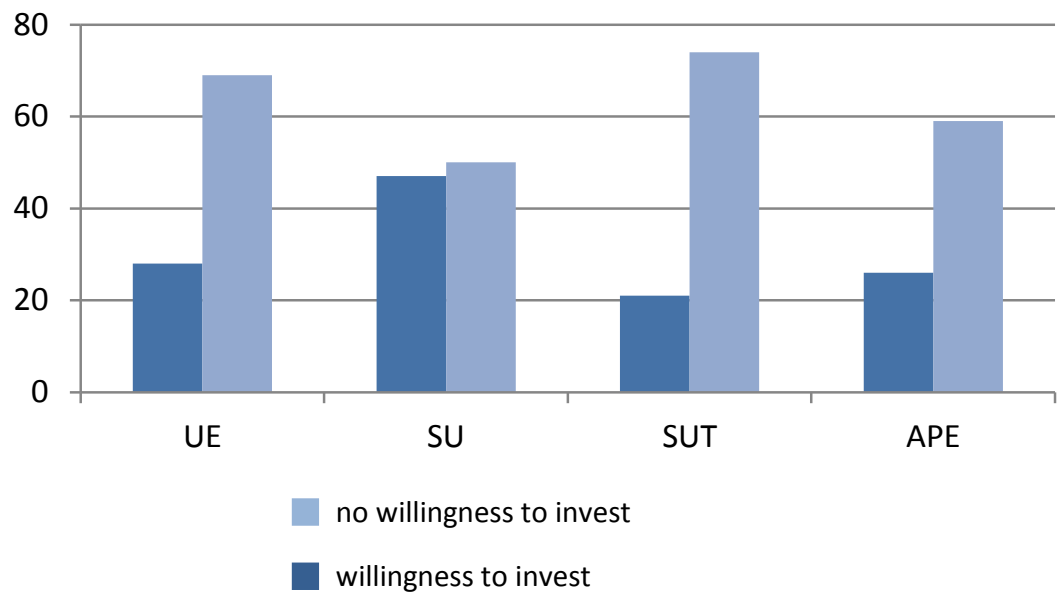

Figure 4. Students willingness to invest in risky financial instruments

Source: Primary research.

One-third of students consider making investments in the future. Surprisingly, the least willing to invest are students of Silesian University of Technology (22\%), in contrast to students of Silesian University - 48\%. Students who declared their readiness to investing raise their funds mostly from pocket money (43\%), on the second place is income from work (41\%), other source of income (pensions, alimonies, scholarships) constitute $16 \%$. Differences between universities were observed and are presented in Figure 5. 


\section{University of Economics}

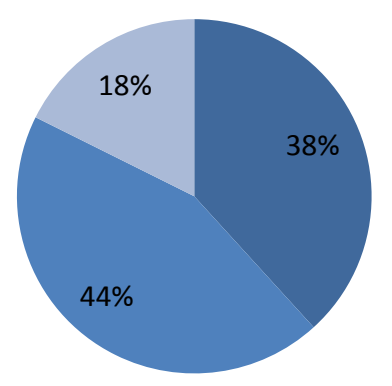

Silesian University of Technology

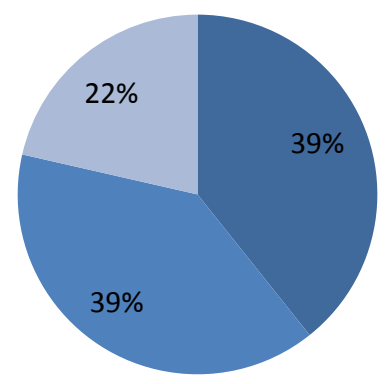

$$
\begin{aligned}
& \text { pocket money } \\
& \text { income from work } \\
& \text { pocket money }
\end{aligned}
$$

\section{University of Silesia}

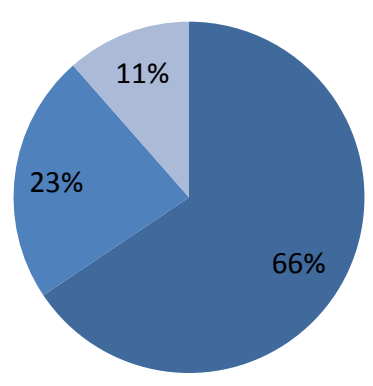

Academy of Physical Education

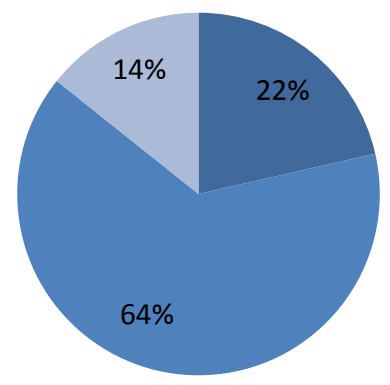

Figure 5. Source of raising funds among students from respective universities

Source: Primary research.

The biggest difference is between students from University of Silesia and Academy of Physical Education. Students who are willing to invest from University of Silesia are raising funds mainly from pocket money (66\%), while students from Academy of Physical Education receive their income mostly from work (64\%). On University of Economics and Silesian University of Technology 
the percentage share of students who want to invest and raise fund from pocket money and work is comparable - around $40 \%$.

Definitely students do not have experience in investing. Only $8 \%$ of students made investments in the last 12 months. If they decide to allocate funds in investments, it usually do not exceed $10 \%$ of the student's income. The income come mostly from the pocket money, but students invest also the money they receive from work.

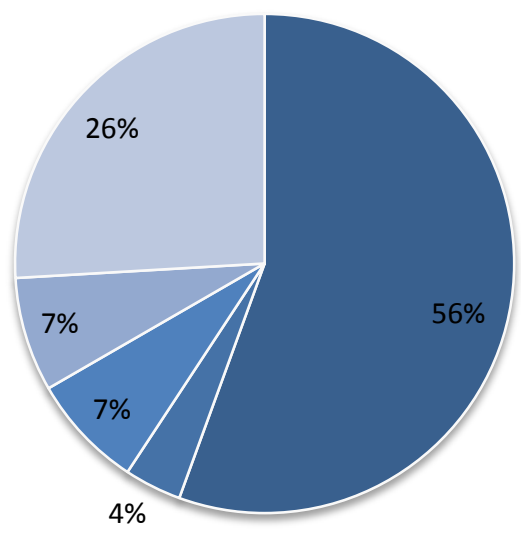

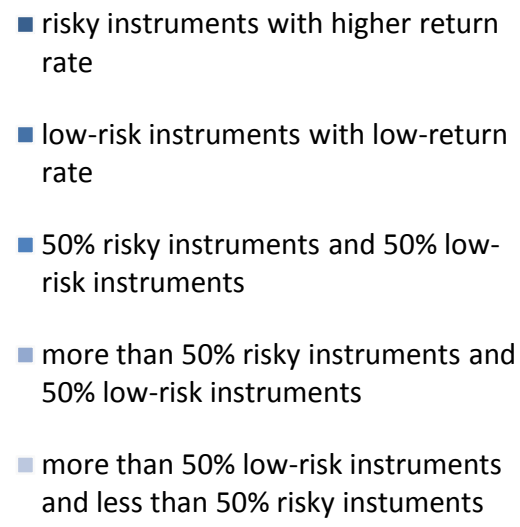

Figure 6. Forms of investment options chose by students

Source: Primary research.

Regarding the form of investment, majority of students prefer risky instruments with higher return rate (56\%). $26 \%$ of students prefer the diversified investment option which include 50\% low-risk instruments and less than 50\% risky instruments. The most popular type of investment instruments chose by students who already made investments were currencies $(41 \%)$, stocks $(28 \%)$, precious metals $(20 \%)$, derivatives $(9 \%)$. Students rarely make investment in real estates $(2 \%)$. In majority students do not have clearly defined preferences regarding the way they make investments (48\%). 33\% of them invested via stock exchange, and 19\% chose brokerage firms. While making investment decisions, students put most attention to benefits associated with the investment undertaken (29\%). Risk (19\%), own contribution (13\%), time of investment (12\%) are also important for them. The least attention they pay to the accessibility of the investment offer (4\%). 


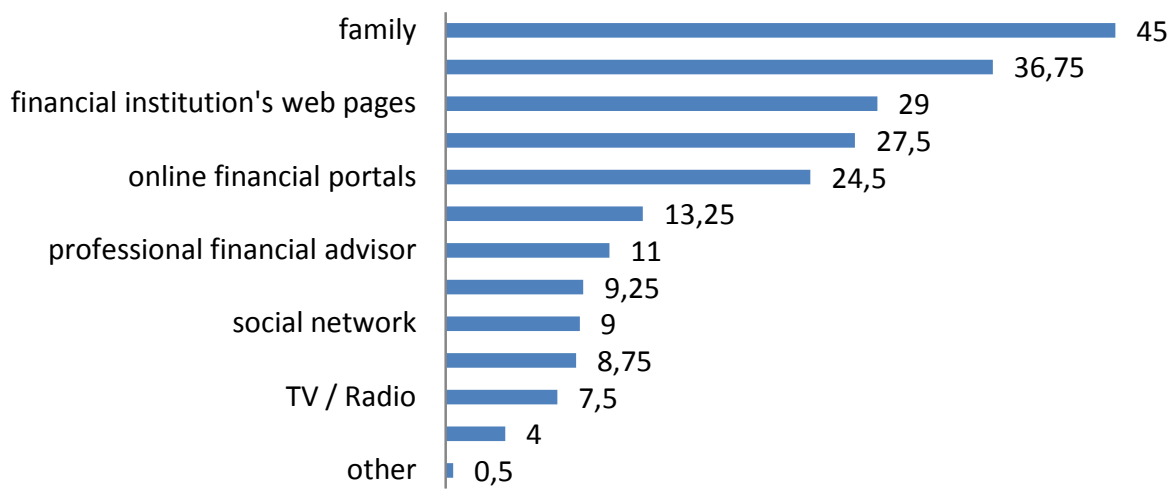

Figure 7. Sources of knowledge while making financial decisions by students (in \%)

Source: Primary research.

The most important factor used by students while making financial decisions is their family. They also use their general knowledge, refer to the financial institution's web pages, make use of their friends knowledge and search information on online financial portals. Newspapers are the least use form of obtaining financial information amongst students.

Almost half of all students asked to assess the level of their knowledge estimated it at basic level (46\%). 30\% of them claim that the level of their knowledge is intermediate, and $6 \%$ think is upper intermediate and advance.

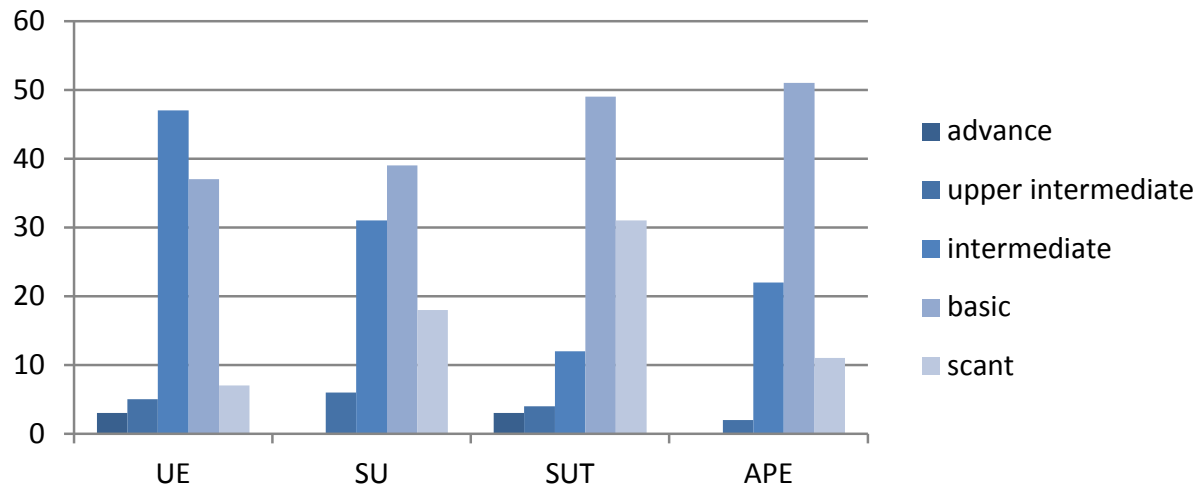

Figure 8. Students appraisal of their knowledge regarding financial markets and investments opportunities

Source: Primary research. 
The students assessed their knowledge differently on several universities. Nearly half of students of Finance and Accounting (University of Economics) claim that their knowledge is on intermediate level, while $81 \%$ of PS students assessed that their knowledge is on basic or scant level. When students were asked to compare their knowledge to the society at large students of University of Economics believe that their financial knowledge is higher, while the rest of the students believe that their financial awareness is at the comparable level with the rest of the society.

\section{CONCLUSIONS}

The most noticeable conclusion of the conducted research is that students in vast majority declare their willingness to save. More than half of them already save and they spend, on average, one-third of their income for this purpose. However no significant relation between the source of raising fund and the propensity to saving was observed.

Surprisingly one-third of students declare their readiness to make investments in the future.

Taking into account students from all probed universities no substantial correlation between the source of rising fund and their readiness to investing was observed. Among students who already have some experience in investing risky financial instruments with higher return rate were eagerly chosen. This is reflected in the research and literature describing consumer behaviour on the financial markets regarding the relationship between age and risk propensity.

The students' knowledge is insufficient and this is reflected in the results of research showing a small number of students who made an attempt to invest a surplus of money. In making financial decisions, they mainly refer to the opinions and knowledge of the family and to their general knowledge. They make little use of reliable sources provided by specialists and which are widely accessible. Insufficient knowledge about the product offer results in the fact that they use the product offer to a small extant. Students predominantly leave cash surplus on the current account or use open savings accounts, thus they do not use the available options offered by financial institutions. Little financial knowledge results in a lack of complacency and general activity on the financial markets. Financial institutions wanting to attract a large group of potential clients should present the offer in a more accessible way. When students better understand the functioning of the market and the product offer, they will be able to trust them more and entrust their money in the form of savings or investment. 


\section{BIBLIOGRAFIA}

2015 Little Book on Financial inclusion, 2015, World Bank Group.

Baranowska-Skimina A., 2011, Ulubione produkty i ustugi finansowe Polaków, www.egospodarka.pl (20 March 2018)

Das S., 2015, A Dissertation Report on Factors affecting financial inclusion: A study in Rourkela, School of Management National Institute of Technology, Rourkela.

Frączek B., 2015, The Sources of Raising Money as the Factor Influencing the Level of Financial Literacy and Degree of the Financial Inclusion, „International Journal of Innovative Business Strategies", Infonomics Society.

Frączek B., Klimontowicz M., 2015, Financial literacy and its influence on young customers' decision factors, ,Journal of International Management”, No. 3.

Frączek B., 2012, Analiza czynników wpływających na oszczędzanie i inwestowanie gospodarstw domowych, „Studia Ekonomiczne. Zeszyty Naukowe Uniwersytetu Ekonomicznego w Katowicach", nr 122, Katowice.

Frączek B., 2010, Ocena atrakcyjności poszczególnych form oszczędzania i inwestowania, [w:] J. Harasim (red.), Oszczędzanie i inwestowanie w teorii i praktyce, Wyd. PTE, O/Katowice.

Jarecki W., 2018, Praca i dochody studentów, „Polityka Społeczna”, nr 1/2010, www.ipiss.com.pl (20 March 2018).

Kenny T., 2017, The difference between stocks and bonds, www.thebalance.com (20 March 2018).

Kiezel E., Burgiel A., 2017, Wiedza ekonomiczna konsumentów a racjonalność ich zachowań, Wydawnictwo C.H. Beck, Warszawa.

OECD, 2014, Financial Education for Youth: The Role of Schools, OECD Publishing, Paris.

Oferta dla klientów indywidualnych - oszczędności, www.pkobp.pl (22 March 2018).

Oferta dla klientów indywidualnych - inwestycje, www.ingbank.pl (22 March 2018).

Smyczek S., 2012, Nowe trendy $w$ zachowaniach konsumentów na rynkach finansowych, Placet, Warszawa.

Smyczek S., 2001, Zachowania konsumentów na rynku usług bankowych, Wydawnictwo Uczelniane Akademii Ekonomicznej im. Karola Adamieckiego w Katowicach.

Smyczek S., 2007, Modele zachowań konsumentów na rynku ustug finansowych, Wydawnictwo Uczelniane Akademii Ekonomicznej im. Karola Adamieckiego w Katowicach.

Stan i struktura ludności wedlug wieku w latach 1989-2016, www.stat.gov.pl (20 March 2018)

Światowy G., 2006, Zachowania konsumentów. Determinanty oraz metody poznania i ksztaltowania, PWE, Warszawa

[www1] https://bossafund.pl/edukacja/abc-funduszy/rodzaje-funduszy-inwestycyjnych (27 March 2018). 


\section{ŹRÓDŁA POZYSKIWANIA DOCHODÓW PRZEZ POLSKICH STUDENTÓW ZE ŚLĄSKICH UCZELNI, ICH STOSUNEK DO OSZCZĘDZANIA, INWESTOWANIA I PODEJMOWANIA RYZKA}

\section{Streszczenie}

W dzisiejszych czasach istotnym problemem na rynkach finansowych jest niewystarczający poziom włączenia finansowego rozumiany jako dostępność i korzystanie z podstawowych usług finansowych, takich jak posiadanie rachunku bankowego, oszczędności i pożyczek. Celem tego artykułu jest zbadanie stosunku do oszczędzania, inwestowania i ryzyka studentów, jako ważnej grupy potencjalnych klientów instytucji finansowych. W tym celu przeprowadzono ankietę wśród losowo wybranych studentów czterech śląskich uczelni. Wyniki badań pokazały w jakim stopniu uczniowie korzystają z dostępnej oferty produktowej instytucji finansowych, ich podejścia do korzystania z tej oferty, poziomu wiedzy finansowej, która ma wpływ na poczucie bezpieczeństwa i swobodne poruszanie się na rynkach finansowych. Nie zaobserwowano znaczących różnic pomiędzy studentami poszczególnych uczelni. Większość studentów ocenia swoją wiedzę na poziomie podstawowym. Zdecydowana większość studentów posiada oszczędności, jednakże wąskie grono studentów deklaruje chęć inwestycji w walory ryzykowne.

Słowa kluczowe: oszczędzanie, inwestowanie, stosunek do ryzyka, edukacja finansowa, włączenie finanowe, finanse osobiste studentów, oferta usług finansowych, poczucie bezpieczeństwa na rynkach finansowych. 